\title{
Thermal stability of proteins in the presence of aprotic ionic liquids
}

\author{
Hidetaka Noritomi, Ken Minamisawa, Reo Kamiya, Satoru Kato
}

Department of Applied Chemistry, Tokyo Metropolitan University, Minami-Ohsawa, Tokyo, Japan.

Email: noritomi@tmu.ac.jp

Received 6 December 2010; revised 24 December 2010; accepted 28 December 2010.

\begin{abstract}
Thermal stability of lysozyme dissolved in aqueous solutions was examined in the presence of water-miscible aprotic ionic liquids consisting of 1-ethyl3-methylimidazolium cation and several kinds of anions. Addition of ionic liquids to an aqueous solution containing lysozyme prevented unfolded proteins from aggregating irreversibly at high temperatures. The thermal denaturation curve of lysozyme with ionic liquids was entirely shifted to higher temperature, compared with that without ionic liquids. The remaining activity of lysozyme after the heat treatment was markedly dependent upon the kind and concentration of ionic liquids. The remaining activities of lysozyme with 1.5 M 1-ethyl-3-methylimidazolium tetrafluoroborate ([emim] $\left.\left[\mathrm{BF}_{4}\right]\right)$ and $0.1 \mathrm{M}$ 1ethyl-3-methylimidazolium trifluoromethanesulfonate ([emim][Tf]) exhibited 88 and $68 \%$ after the heat treatment at $90^{\circ} \mathrm{C}$ for $30 \mathrm{~min}$, respectively, although that without ionic liquids was perfectly lost.
\end{abstract}

Keywords: Thermal Stability; Lysozyme; Ionic Liquid; Remaining Activity

\section{INTRODUCTION}

In resent years, the production and applications of proteins have rapidly increased, not only in biochemical research, but also in the chemical, food, and pharmaceutical industries, since proteins can exhibit exquisite biological activities. Three-dimensional structure of proteins is kept by several weak interactions such as ionic effects, hydrogen bonds, and hydrophobic interactions. When these weak interactions are disrupted by changes of several different kinds in the environment of proteins, proteins are denatured, and inactivated via their unfolding [1-3]. In particular, modest heating can easily disrupt several of these stabilizing interactions. Thermal denaturation is a serious problem not only in the separation and storage of proteins but also in the processes of biotransformation, drug production, and food manufacturing. Several strategies have so far been proposed in order to prevent thermal denaturation [4-11,21]. They include chemical modification, immobilization, genetic modification, and addition of stabilizing agents. The addition of stabilizing agents to an aqueous solution containing proteins is one of the most convenient methods for minimizing thermal denaturation. It has been reported that polyols, sugars, amino acids, amino acid derivatives, methylamines, and inorganic salts are available for improving protein stability. However, these additives do not sufficiently prevent irreversible protein aggregation or some of them are no longer stable at high temperatures.

Ionic solvent that is liquid at room temperature has attracted increasing attention as a green solvent for the chemical processes because of the lack of vapor pressure, the thermal stability, and the high polarity $[12,13]$. Chemical and physical properties of ionic liquids can be changed by the appropriate modification of organic cations and anions, which are constituents of ionic liquids. Biotransformation in ionic liquids has increasingly been studied $[14,15,34]$. We have found that the activity of protease is highly maintained not only in water-immiscible aprotic ionic liquids but also in water-miscible aprotic ionic liquids as well $[22,23]$. On the other hand, it has been reported that protic ionic liquids keep the stability of proteins in an aqueous solution at high temperatures [24,25], and amyloid fibrils of proteins are dissolved in protic ionic liquids and are refolded by dilution with an aqueous solution [32]. Moreover, aprotic ionic liquids can refold the denatured protein [33].

In our present work, we have focused on the remaining activity of proteins after heat treatment in order to address a question of whether or not water-miscible aprotic ionic liquids consisting of 1-ethyl-3-methylimidazolium cations and several kinds of anions affect the thermostability of proteins in aqueous solutions. As a model protein, chicken egg-white lysozyme has been employed, since it is well investigated regarding its structure, properties, 
functions, and thermostability [16-18,24,25].

\section{EXPERIMENTAL}

\subsection{Materials}

Lysozyme from chicken egg while (EC 3.2.1.17, 46400 units/mg solid, $\mathrm{MW}=14300, \mathrm{pI}=11.1$ ) and Micrococcus lysodeikticus (ATCC No. 4698) were purchased from Sigma-Aldrich Co. (St. Louis, USA). 1-Ethyl-3-methylimidazolium trifluoromethanesulfonate ([emim][Tf]) (98\% purity) was supplied from Shikoku Kasei Co. (Kagawa, Japan). 1-Ethyl-3-methylimidazolium tetrafluoroborate ([emim] $\left.\left[\mathrm{BF}_{4}\right]\right)(99 \%$ purity) and 1-ethyl-3methylimidazolium chloride ([emim][Cl]) (99\% purity) were obtained from Kanto Chemical Co. (Tokyo, Japan). The structures of ionic liquids used in the present work are shown in Figure 1. The other reagents were purchased from Sigma-Aldrich Co. (St. Louis, USA). All solvents used were of guaranteed grade and commercially available, and were used without further purification.

\subsection{Heat Treatment of Lysozyme}

In a typical experiment, the aqueous solution containing $100 \mu \mathrm{M}$ lysozyme was prepared by dissolving lysozyme to $0.01 \mathrm{M}$ phosphate buffer solution at $\mathrm{pH} 7.0$. One $\mathrm{mL}$ of lysozyme aqueous solution with or without a requisite quantity of ionic liquids in a 4-mL screw-cap vial was placed in thermostated silicone oil bath at $90^{\circ} \mathrm{C}$ for 30 $\min$.

\subsection{Measurement of Remaining Activity of Lysozyme}

Lysozyme catalyzes hydrolysis of the $\beta-1,4$ glycosidic linkage between the $N$-acetylmuramic acid and $N$-acetylglucosamine components of peptidoglycan. This causes breakdown and removal of peptidoglycan from the bacterium which results in cell bursting or lysis in natural hypotonic solutions [16]. After the heat treatment, an aqueous solution of lysozyme was cooled in thermostated water bath at $25^{\circ} \mathrm{C}$ for $10 \mathrm{~min}$. After $10 \mu \mathrm{L}$ of the cooled aqueous solution of lysozyme was added to $3 \mathrm{~mL}$ of $0.01 \mathrm{M}$ phosphate buffer solution at $\mathrm{pH} 7$ containing $200 \mathrm{mg} / \mathrm{L}$ Micrococcus lysodeikticus at $25^{\circ} \mathrm{C}$, the absorbance was continuously measured at $450 \mathrm{~nm}$ by

\begin{tabular}{|c|c|c|c|}
\hline Ionic liquid & Structure & m.p. $\left({ }^{\circ} \mathrm{C}\right)$ & $\begin{array}{c}\text { Water } \\
\text { miscibility }\end{array}$ \\
\hline$[\mathrm{emim}][\mathrm{Tf}]$ & & -9 & Miscible \\
\hline$[\mathrm{emim}]\left[\mathrm{BF}_{4}\right]$ & & 14.6 & Miscible \\
\hline$[\mathrm{emim}][\mathrm{Cl}]$ & & 78 & Miscible \\
\hline
\end{tabular}

Figure 1. Structures of ionic liquids used in the present work.
UV/vis spectrophotometer (Ubest-55, Japan Spectroscopic Co. Ltd.). Bacterial lysis obeys a first order reaction. The lysis rate constant $(\mathrm{k})$ is calculated by

$$
\ln \left(A^{0}{ }_{450} / A_{450}\right)=k t
$$

where $t, A^{0}{ }_{450}$, and $A_{450}$ are the reaction time, the absorbance of the substrate solution at $450 \mathrm{~nm}$ at $T=0$, and the absorbance of the substrate solution at $450 \mathrm{~nm}$ at $T=t$, respectively. The remaining activity ( $\mathrm{R}$. A.) is defined as

$$
\text { R.A. }=100 x k / k_{0}
$$

where $k_{\mathrm{o}}$ and $k$ are the lysis rate constants of native and heat-treated enzymes at $25^{\circ} \mathrm{C}$, respectively. Data for remaining activity is the average of triple measurements.

\section{RESULTS AND DISCUSSION}

\subsection{Thermal Inactivation of Lysozyme}

When proteins dissolved in an aqueous solution are placed at high temperatures, most of proteins are immediately unfolded due to the disruption of weak interactions, including ionic effects, hydrogen bonds, and hydrophobic interactions, which are prime determinants of protein tertiary structures. In addition, the intermolecular aggregation among unfolded proteins, the incorrect structure formation, and the chemical deterioration reactions in unfolded proteins proceed as shown in Figure 2 $[1-3,19,20]$. In particular, protein aggregation easily occurs upon the exposure of the hydrophobic surfaces of a protein, and this phenomenon becomes the major problem because of the irreversible inactivation. On the other hand, when a heated solution of denatured proteins without protein aggregation is slowly cooled back to its normal biological temperature, the reverse process, which is renaturation with restoration of protein function, often occurs. Accordingly, if stabilizing agents can sufficiently prevent irreversible aggregation of unfolded proteins, it is expected that unfolded proteins are refolded by cooling

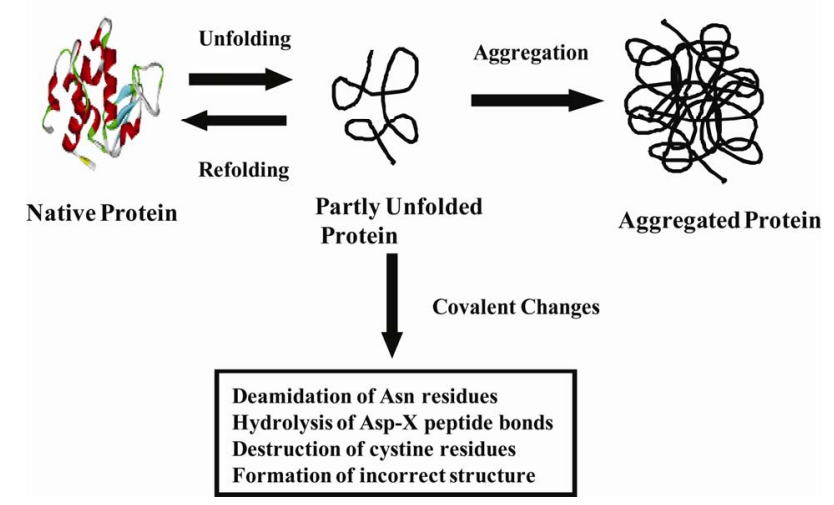

Figure 2. Schematic illustration of thermal denaturation of proteins. 
treatment, and the high remaining activity is obtained.

Table 1 represents the remaining activities of lysozyme in the presence of various kinds of additives after heat treatment at $90^{\circ} \mathrm{C}$ for $30 \mathrm{~min}$. Lysozyme without additives lost its activity perfectly after heat treatment. Native lysozyme solution immedieately became turbid due to the formation of protein aggregation, as soon as heat treatment was carried out, as shown in Figure 3(b). It has been reported that the precipitation due to protein aggregation is observed above $10 \mu \mathrm{M}$ lysozyme [18]. As lysozyme concentration in the present work was $100 \mu \mathrm{M}(1.4 \mathrm{mg} / \mathrm{mL})$ which was ten times higher than that, the formation of protein aggregation was dramatically accelerated. Inorganic salts and glycerol used as a conventional stabilizing agent inhibited the formation of protein aggregation, and exhibited thermal stabilization to some extent. On the other hand, [emim] $\left[\mathrm{BF}_{4}\right]$ and $[\mathrm{emim}][\mathrm{Tf}]$ showed high remaining activities. The lysozyme solution in the presence of ionic liquids was transparent after heat treatment, as seen in

Table 1. Remaining activities of lysozyme in the presence of various kinds of additives after heat treatment at $90^{\circ} \mathrm{C}$ for $30 \mathrm{~min}$.

\begin{tabular}{lc}
\hline Additive & Remaining activity (\%) \\
\hline None & 0 \\
1.0 M Sodium chloride & 29 \\
0.3 M Ammonium sulfate & 41 \\
2.8 M Glucose & 8 \\
5.4 M Glycerol & 15 \\
7 mM $\beta$-Cyclodextrin & 0 \\
0.01 M Triton-X & 0 \\
$2 \%$ Pectin & 0 \\
0.7 M Urea & 6 \\
$0.1 \mathrm{M}$ [emim][Tf] & 68 \\
$1.5 \mathrm{M}$ [emim][BF $]$ & 88 \\
$1.5 \mathrm{M}[\mathrm{emim}][\mathrm{Cl}]$ & 3.4 \\
\hline
\end{tabular}

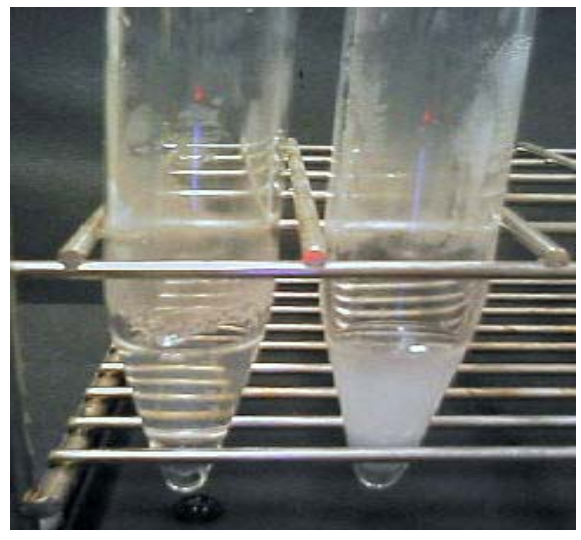

(a)

(b)

Figure 3. Photographs of lysozyme solutions after heat treatment at $90^{\circ} \mathrm{C}$ for $30 \mathrm{~min}$ : (a) lysozyme solution with $1.5 \mathrm{M}$ [emim $]\left[\mathrm{BF}_{4}\right]$, (b) lysozyme solution without $[\mathrm{emim}]\left[\mathrm{BF}_{4}\right]$.
Figure 3(a). When lysozyme solution in the presence of protic ionic liquids (alkylammonium formates) is heated at $90^{\circ} \mathrm{C}$, protein aggregation is prevented, and any cloudy appearance is absent [25]. The hydrophobic core of lysozyme unfolded by heat interacts with the cation of ionic liquids, and cation adsorption results in acquisition of a net positive charge preventing aggregation via electrostatic repulsion [24].

Figure 4 shows the relationship between temperature and the remaining activity of lysozyme in aqueous solutions containing water-miscible ionic liquids after the heat treatment for $30 \mathrm{~min}$. As seen in the figure, the dependence of the remaining activity on the temperature exhibited the sigmoid curve. The remaining activity of lysozyme without ionic liquids gradually decreased with an increase in temperature below $70^{\circ} \mathrm{C}$, accompanied with the formation of precipitation due to protein aggregation, drastically dropped in the range from 70 to $80^{\circ} \mathrm{C}$, and was then lost at temperatures of $80^{\circ} \mathrm{C}$ or higher. The transition temperature was exhibited around $75^{\circ} \mathrm{C}$, similar to the case measured by differential scanning calorimetry [24]. On the other hand, the remaining activity of lysozyme with $1.5 \mathrm{M}$ [emim][Cl] gradually decreased with an increase in temperature below $75^{\circ} \mathrm{C}$, and drastically dropped in the range from 80 to $90^{\circ} \mathrm{C}$. The remaining activity of lysozyme with $1.5 \mathrm{M}$ [emim] $\left[\mathrm{BF}_{4}\right]$ was highly maintained below $80^{\circ} \mathrm{C}$, gradually decreased with temperature, and the remaining activity depicted $60 \%$ at $98^{\circ} \mathrm{C}$. Similarly, the remaining activity of lysozyme with $0.1 \mathrm{M}$ [emim][Tf] was highly retained below $80^{\circ} \mathrm{C}$, gradually decreased with temperature below $92^{\circ} \mathrm{C}$, drastically dropped in the range from 92 to $98^{\circ} \mathrm{C}$, and was then lost at $98^{\circ} \mathrm{C}$. These results indicated that the addition of aprotic ionic liquids to an aqueous solution of lysozyme effectively improved the thermal stability of lysozyme at high temperatures.

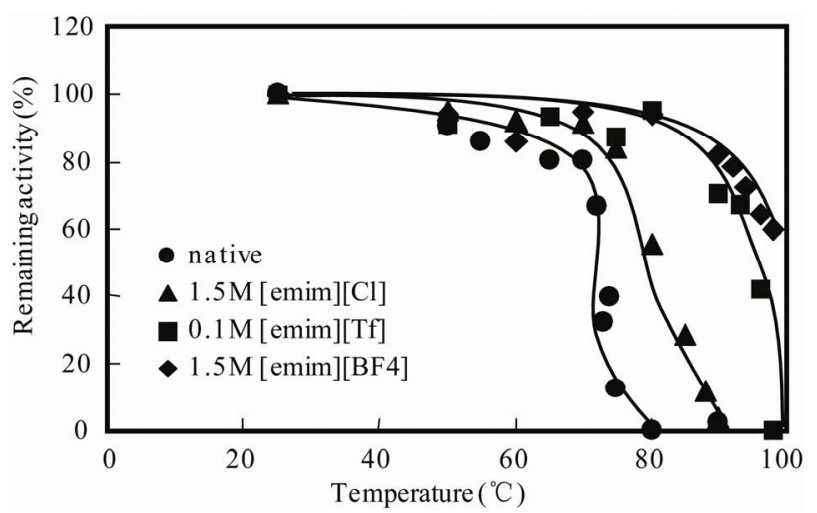

Figure 4. Thermal denaturation curves of lysozyme with or without ionic liquid. The aqueous solution of $100 \mu \mathrm{M}$ lysozyme with or without ionic liquids was incubated in a silicone oil bath thermostated at requisite temperature for $30 \mathrm{~min}$. 


\subsection{Refolding of Lysozyme with Ionic Liquids}

Figure 5 shows the time course of remaining activity in the presence of ionic liquids at $25^{\circ} \mathrm{C}$ after the heat treatment at $90^{\circ} \mathrm{C}$ for $30 \mathrm{~min}$. The remaining activity of lysozyme with $1.5 \mathrm{M}$ [emim] $\left[\mathrm{BF}_{4}\right]$ or $0.1 \mathrm{M}$ [emim][Tf] increased with incubation time, and reached the equilibrium at 2 and $7 \mathrm{~min}$, respectively. In thermal denaturation of lysozyme without protein aggregation, when the hydrophobic core of proteins is exposed, but the disulfide bonds keep intact, denatured proteins spontaneously refold to their native structures on cooling after thermal denaturation [26-30]. The refolding of thermally-denatured proteins is enhanced in the presence of protic ionic liquids such as alkylammonium nitrate and alkylammonium formates [24,25]. Moreover, N'-alkyl and N'-( $\omega$ hydroxyalkyl) $\mathrm{N}$-methylimidazolium chlorides refold denatured proteins such as hen egg white lysozyme and the single-chain antibody fragment ScFvOx [33].

\subsection{Dependence of the Remaining Activity of Lysozyme on the Concentration of Ionic Liquids via Heat Treatment}

Figure 6 shows the plot of the remaining activity of lysozyme against the concentration of ionic liquids after the heat treatment at $90^{\circ} \mathrm{C}$ for $30 \mathrm{~min}$. The remaining activity was strongly dependent on the concentration of [emim] $\left[\mathrm{BF}_{4}\right]$ or $[\mathrm{emim}][\mathrm{Tf}]$, while the effect of concentration of $[\mathrm{emim}][\mathrm{Cl}]$ was not observed. The remaining activity in the presence of $[\mathrm{emim}]\left[\mathrm{BF}_{4}\right]$ increased with an increase in the concentration of $[\mathrm{emim}]\left[\mathrm{BF}_{4}\right]$ and reached a plateau around $0.8 \mathrm{M}$. The remaining activity in the presence of [emim][Tf] dramatically increased with increasing the concentration of [emim][Tf], the maximal remaining activity was obtained at $0.1 \mathrm{M}$ [emim][Tf], and

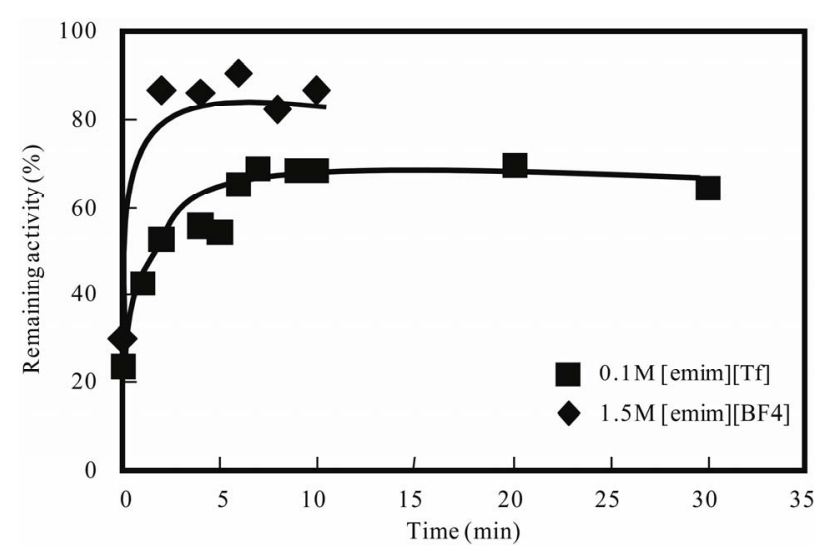

Figure 5. Time dependence of remaining activity of lysozyme with ionic liquids on cooling at $25^{\circ} \mathrm{C}$ after heat treatment at $90^{\circ} \mathrm{C}$ for $30 \mathrm{~min}$. After heat treatment, the aqueous solution of $100 \mu \mathrm{M}$ lysozyme with $0.1 \mathrm{M}$ [emim][Tf] or $1.5 \mathrm{M}$ [emim] $\left[\mathrm{BF}_{4}\right]$ was incubated in a water bath thermostated at $25^{\circ} \mathrm{C}$. then decreased steeply. After heat treatment, the remaining activity of lysozyme increases with an increase in the concentration of ethylammonium formate and 2-methoxyethylammonium formate, while the remaining activity increases at low concentration of propylammonium formate, but at higher concentrations of propylammonium formate the protein spontaneously denatures [25]. Thus, the dependence of concentration of ionic liquids on the remaining activity of proteins changes by switching from one ionic liquid to another.

\subsection{Dependence of the Remaining Activity of Lysozyme on the Concentration of Ionic Liquids after the Incubation at $25^{\circ} \mathrm{C}$}

Figure 7 shows the plot of the remaining activity of lysozyme against the concentration of ionic liquids after the incubation at $25^{\circ} \mathrm{C}$ for $30 \mathrm{~min}$ without the heat treatment. The remaining activity in the presence of $[\mathrm{emim}][\mathrm{Cl}]$ or [emim $]\left[\mathrm{BF}_{4}\right]$ was undependent on the concentration of

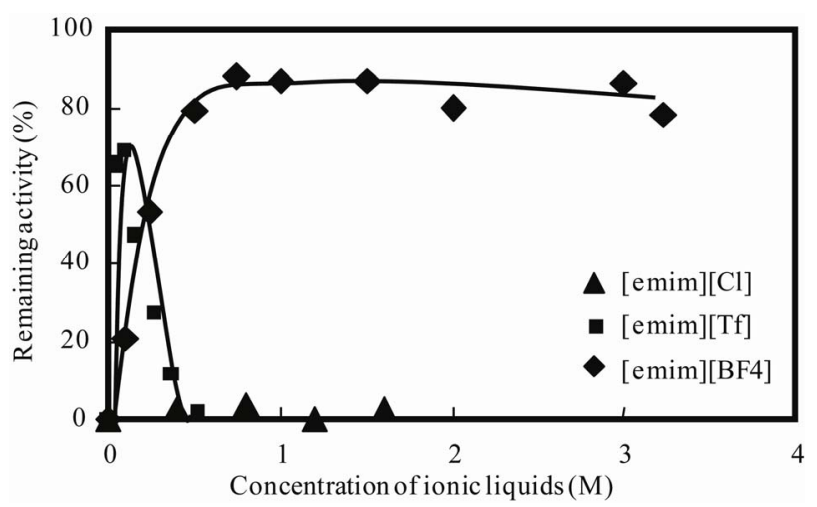

Figure 6. Effect of concentration of ionic liquids on remaining activity of lysozyme after heat treatment at $90^{\circ} \mathrm{C}$ for $30 \mathrm{~min}$. The aqueous solution of $100 \mu \mathrm{M}$ lysozyme with requisite concentration of ionic liquids was incubated in a silicone oil bath thermostated at $90^{\circ} \mathrm{C}$ for $30 \mathrm{~min}$

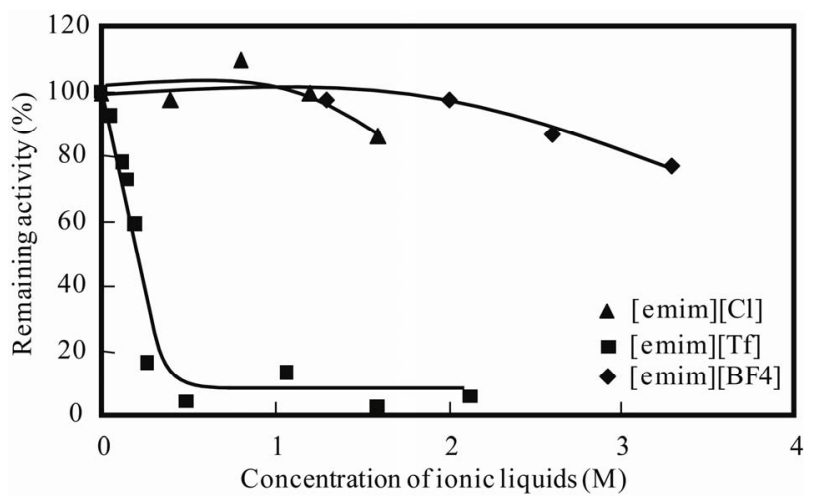

Figure 7. Effect of concentration of ionic liquids on remaining activity of lysozyme during incubation at $25^{\circ} \mathrm{C}$. The aqueous solution of $100 \mu \mathrm{M}$ lysozyme with requisite concentration of ionic liquids was incubated in a water bath thermostated at $25^{\circ} \mathrm{C}$ for $30 \mathrm{~min}$. 
ionic liquids till $1.2 \mathrm{M}$ [emim][Cl] or $2.0 \mathrm{M}[\mathrm{emim}]\left[\mathrm{BF}_{4}\right]$ and gradually droped, while it in the presence of [emim] [Tf] decreased with an increase in the concentration of [emim][Tf]. These results indicate that [emim][Tf] tends to strongly function as a denaturant, compared with $[\mathrm{emim}][\mathrm{Cl}]$ and $[\mathrm{emim}]\left[\mathrm{BF}_{4}\right]$. Electrolytes promote or inhibit the stability of proteins according to the kind of electrolytes [35]. Moreover, chemical denaturants, such as urea and guanidine hydrochloride, can promote dissolution of inclusion bodies, which are protein aggregation formed by prokaryotic expression systems [31]. Similarly, [emim][Tf] inhibits the formation of protein aggregation at low [emim][Tf] concentrations, but it mainly denatures proteins at higher [emim] $[\mathrm{Tf}]$ concentrations.

\subsection{Time Course of Remaining Activity of Lysozyme via Heat Treatment with or without Ionic Liquids}

Figure 8 shows time course of remaining activity of lysozyme with or without ionic liquids through the heat treatment at $90^{\circ} \mathrm{C}$. The remaining activity of lysozyme without ionic liquids dramatically decreased with an increase in time, accompanied with the formation of protein aggregation, and was almost lost at $10 \mathrm{~min}$. It has been reported that the remaining activity in the thermal denaturation process accompanied with the formation of protein aggregation follows first-order kinetics [18]. As seen in the figure, the relationship of the remaining activity of proteins in the absence of ionic liquids with heat treat time could be correlated by first-order kinetics. On the other hand, $1.5 \mathrm{M}$ [emim] $\left[\mathrm{BF}_{4}\right]$ or $0.1 \mathrm{M}$ [emim] [Tf] prevented the thermal inactivation of lysozyme. In the presence of ionic liquids the turbidity of solutions due to protein aggregation was not observed through heat treatment. This indicates that the thermal inactivation mainly

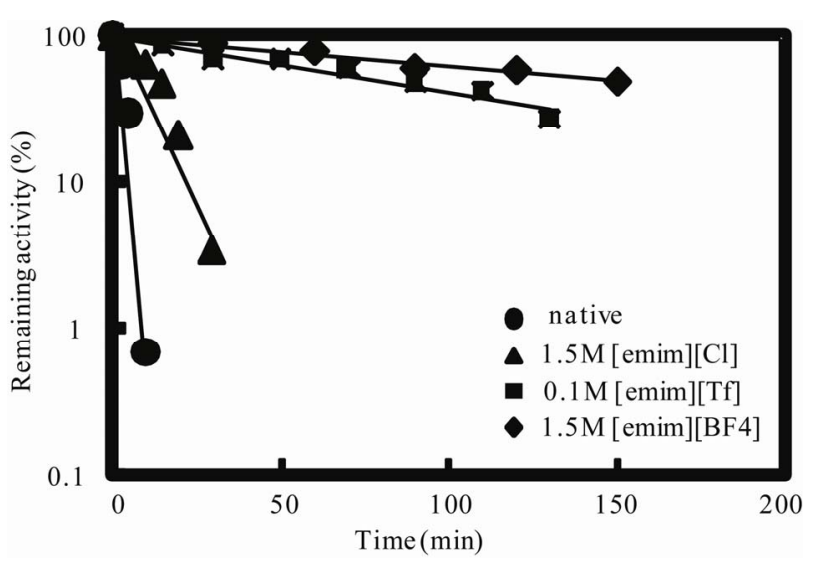

Figure 8. Time dependence of remaining activity with or without ionic liquids after heat treatment at $90^{\circ} \mathrm{C}$. The aqueous solution of $100 \mu \mathrm{M}$ lysozyme with or without ionic liquids was incubated in a silicone oil bath thermostated at $90^{\circ} \mathrm{C}$.
Table 2. Rate constants and half lives of inactivation of lysozyme at $90^{\circ} \mathrm{C}$.

\begin{tabular}{lcc}
\hline Ionic liquid & Rate constant $\left(\mathrm{min}^{-1}\right)$ & Half life $(\mathrm{min})$ \\
\hline none & 0.43 & 1.6 \\
$1.5 \mathrm{M}[\mathrm{emim}][\mathrm{Cl}]$ & 0.065 & 11 \\
$0.1 \mathrm{M}[\mathrm{emim}][\mathrm{Tf}]$ & 0.0081 & 86 \\
$1.5 \mathrm{M}[\mathrm{emim}]\left[\mathrm{BF}_{4}\right]$ & 0.0049 & 141 \\
\hline
\end{tabular}

results from the covalent change as shown in Figure 2. The plots of remaining activity versus heat treatment time on thermal inactivation of lysozyme in the presence of ionic liquids followed first-order kinetics on linearity. It has been reported that the thermal inactivation of lysozyme obeyed first-order kinetics when it irreversibly proceeded by the covalent change without the formation of protein aggregation [17]. Table 2 represents rate constants and half lives of inactivation of lysozyme with or without ionic liquids calculated from the fitting curves. The half lives with $1.5 \mathrm{M}$ [emim] $\left[\mathrm{BF}_{4}\right], 0.1 \mathrm{M}$ [emim] [Tf], and $1.5 \mathrm{M}$ [emim][Cl] were 88,54 , or 6.9 times longer than that without ionic liquids, respectively.

\section{CONCLUSIONS}

We have demonstrated that the remaining activity of lysozyme is sufficiently maintained after heat treatment at high temperatures, since aprotic ionic liquids prevented unfolded proteins from aggregating. The remaining activity of lysozyme markedly depended upon the kind and concentration of ionic liquids. Specifically, [emim][Tf] exhibited thermostabilization effect of proteins at low concentrations, but denatured proteins at high concentrations. When the heat treatment was carried out at $90^{\circ} \mathrm{C}$, the half lives with $1.5 \mathrm{M}$ [emim] $\left[\mathrm{BF}_{4}\right]$ and $0.1 \mathrm{M}[\mathrm{emim}]$ [Tf] were much superior to that with $1.5 \mathrm{M}$ [emim] [Cl].

\section{REFERENCES}

[1] Volkin, D.B. and Klibanov, A.M. (1989) Minimizing protein inactivation, in T.E. Creighton Ed., Protein Function: Practical Approach, 1-24, IRL Press, Oxford.

[2] Klibanov, A.M. (1983) Stabilization of enzymes against thermal inactivation. Advances in Applied Microbiology, 29, 1-28. doi:10.1016/S0065-2164(08)70352-6

[3] Illanes, A. (1999) Stability of biocatalysts. Electronic Journal of Biotechnology, 2, 1-9.

[4] Gerlsma, S.Y. (1968) Reversible denaturation of ribonuclease in aqueous solutions as influenced by polyhydric alcohols and some other additives. Journal of Biological Chemistry, 243, 957-961.

[5] Kaushik, J.K. and Bhat, R. (1998) Thermal stability of proteins in aqueous polyol solutions: Role of the surface tension of water in the stabilizing effect of polyols. Journal of Biological Chemistry. B, 102, 7058-7066.

[6] Back, J.F., Oakenfull, D. and Smith, M.B. (1979) Increased thermal stability of proteins in the presence of sugars and polyols. Biochemistry, 18, 5191-5196. 
doi:10.1021/bi00590a025

[7] Lee, J.C. and Timasheff, S.N. (1981) The stabilization of proteins by sucrose. Journal of Biological Chemistry, 256, 7193-7201.

[8] Santoro, M.M., Liu, Y., Khan, S.M.A., Hou, L.-X. and Bolen, D.W. (1992) Increased thermal stability of proteins in the presence of naturally occurring osmolytes. Biochemistry, 31, 5278-5283. doi:10.1021/bi00138a006

[9] Yancey, P.H., Clark, M.E., Hand, S.C., Bowlus, R.D. and Somero, G.N. (1982) Living with water stress: evolution of osmolyte systems. Science, 217, 1214-1222. doi:10.1126/science.7112124

[10] Arakawa, T., Bhat, R. and Timasheff, S.N. (1990) Why preferential hydration does not always stabilize the native structure of globular proteins. Biochemistry, 29, 19241931. doi:10.1021/bi00459a037

[11] Ikegaya, K. (2005) Kinetic analysis about the effects of neutral salts on the thermal stability of yeast alcohol dehydrogenase. Journal of Biochemistry, 137, 349. doi: $10.1093 / \mathrm{jb} / \mathrm{mvi037}$

[12] Welton, T. (1999) Room-temperature ionic liquids. Solvents for synthesis and calalysis. Chemical Reviews, 99, 2071-2083. doi:10.1021/cr980032t

[13] Greaves, T.L. and Drummond, C.J. (2008) Protic ionic liquids: Properties and applications. Chemical Reviews, 108, 206-237. doi:10.1021/cr068040u

[14] Moniruzzaman, M., Nakashima, K., Kamiya, N. and Goto, M. (2010) Recent advances of enzymatic reactions in ionic liquids. Biochemical Engineering Journal, 48, 295-314. doi:10.1016/j.bej.2009.10.002

[15] Yang, Z. and Pan, W. (2005) Ionic liquids: Green solvents for nonaqueous biocatalysis. Enzyme and Microbial Technology, 37, 19-28. doi:10.1016/j.enzmictec.2005.02.014

[16] Jollès, P. (Ed.), (1996) Lysozymes: Model Enzymes in Biochemistry and Biology. Birkhäuser Verlag, Basel.

[17] Ahern, T.J. and Klibanov, A.M. (1985) The mechanism of irreversible enzyme inactivation at $100^{\circ} \mathrm{C}$. Science, 228, 1280-1284. doi: $10.1126 /$ science. 4001942

[18] Nohara, D., Mizutani, A. and Sakai, T. (1999) Kinetic study on thermal denaturation of hen egg-white lysozyme involving precipitation. Journal of Bioscience and Bioengineering, 87, 199-205. doi:10.1016/S1389-1723(99)89013-6

[19] Lumry, R. and Eyring, H. (1954) Conformation changes of proteins. J. Physical Chemistry, 58, 110-120. doi:10.1021/j150512a005

[20] Zale, S.E. and Klibanov, A.M. (1983) On the role of reversible denaturation (unfolding) in the irreversible thermal inactivation of enzymes. Biotechnology \& Bioengineering, 25, 2221-2230. doi: $10.1002 /$ bit. 260250908

[21] Cioci, F. and Lavecchia, R. (1998) Thermostabilization of proteins by water-miscible additives. Chemical and Biochemical Engineering Quarterly, 12, 191-199.

[22] Noritomi, H., Nishida, S. and Kato, S. (2007) Prote- ase-catalyzed esterification of amino acid in water-miscible ionic liquid. Biotechnology Letters, 29, 1509-1512. doi:10.1007/s10529-007-9416-4

[23] Noritomi, H., Suzuki, K., Kikuta, M. and Kato, S. (2009) Catalytic activity of $\alpha$-chymotrypsin in enzymatic peptide synthesis in ionic liquids. Biochemical Engineering Journal, 47, 27-30. doi:10.1016/j.bej.2009.06.010

[24] Summers, C.A. and Fowers II, R.A. (2000) Protein renaturation by the liquid organic salt ethylammonium nitrate. Protein Science, 9, 2001-2008. doi:10.1110/ps.9.10.2001

[25] Mann, J.P., McCluskey, A. and Atkin, R. (2009) Activity and thermal stability of lysozyme in alkylammonium formate ionic liquids-Influence of cation modification. Green Chemistry, 11, 785-792. doi:10.1039/b900021f

[26] Ibara-Molero, B. and Sanchez-Ruiz, J.M. (1997) Are there equilibrium intermediate states in the urea-induced unfolding of hen egg-white lysozyme? Biochemistry, 36, 9616-9624. doi:10.1021/bi9703305

[27] Griko, Y.V., Freire, E., Privalov, G., Dael, H.V. and Privalov, P.L. (1995) The unfolding thermodynamics of c-type lysozyme-A calorimetric study of the heat denaturation of equine lysozyme. Journal of Molecular Biology, 252, 447-459. doi:10.1006/jmbi.1995.0510

[28] Privalov, P.L. and Khechinashvili, N.N. (1974) A thermodynamic approach to the problem of stabilization of globular protein structure. Journal of Molecular Biology, 86, 665-684. doi:10.1016/0022-2836(74)90188-0

[29] Khechinashvili, N.N., Privalov, P.L. and Tiktopulo, E.I. (1973) Calorimetric investigation of lysozyme thermal denaturation. FEBS Letter, 30, 57-60. doi:10.1016/0014-5793(73)80618-0

[30] Anfinsen, C.B. (1973) Principles that govern the folding of protein chains. Science, 181, 223-230. doi:10.1126/science.181.4096.223

[31] Rudolph, R. and Lilie, H. (1996) In vitro folding of inclusion body proteins. FASEB Journal, 10, 49-56.

[32] Byrne, N. and Angell, C.A. (2009) Formation and dissolution of hen egg white lysozyme amyloid fibrils in protic liquids. Chemistry Communications, 1046-1048. doi:10.1039/b817590j

[33] Lange, C., Patil, G. and Rudolph, R. (2005) Ionic liquids as refolding additives: N'-alkyl and N'-( $\omega$-hydroxyalkyl) N-methylimidazolium chlorides. Protein Science, 14, 2693-2701. doi:10.1110/ps.051596605

[34] Zhao, H. (2005) Effect of ions and other compatible solutes on enzyme activity, and its implication for biocatalysis using ionic liquids. Journal of Molecular Catalysis, B: Enzymatic, 37, 16-25. doi:10.1016/j.molcatb.2005.08.007

[35] Von Hippel, P.H. and Schleich, T. (1969) The effects of neutral salts on the structure and conformational stability of macromolecules in solution. In: Timasheff, S.N. and Fasman, G.D., Eds., Structure and Stability of Biological Macromolecules, Marcel-Dekker, New York, 417-574. 